\title{
Pros and cons of flowers strips for farmers. A review
}

\author{
Roel Uyttenbroeck ${ }^{(1,2)}$, Séverin Hatt ${ }^{(1,3)}$, Aman Paul ${ }^{(1,3)}$, Fanny Boeraeve ${ }^{(1,2)}$, \\ Julien Piqueray ${ }^{(4)}$, Frédéric Francis ${ }^{(1,3)}$, Sabine Danthine ${ }^{(1,3)}$, Michel Frederich ${ }^{(5)}$, \\ Marc Dufrêne ${ }^{(1,2)}$, Bernard Bodson ${ }^{(1,3)}$, Arnaud Monty ${ }^{(1,2)}$
}

(1) University of Liège - Gembloux Agro-Bio Tech. TERRA. AgricultureIsLife. Passage des Déportés, 2. BE-5030 Gembloux (Belgium).E-mail: roel.uyttenbroeck@ulg.ac.be

(2) University of Liège - Gembloux Agro-Bio Tech. Biosystems Engineering. Passage des Déportés, 2. BE-5030 Gembloux (Belgium).

(3) University of Liège - Gembloux Agro-Bio Tech. Agrobiochem. Passage des Déportés, 2. BE-5030 Gembloux (Belgium).

(4) Natagriwal ASBL. Passage des Déportés, 2. BE-5030 Gembloux (Belgium).

(5) University of Liège. Center for Interdisciplinary Research on Medicines. Avenue de l'Hôpital, 1. BE-4000 Liège (Belgium).

Received on April 6, 2015; accepted on January 5, 2016.

Description of the subject. To counteract environmental problems due to agricultural intensification, European farmers can apply agri-environmental schemes in their fields. Flower strips are one example of these schemes, with the aim of supporting biodiversity, leading to an increase in "useful" species groups such as pollinators for crop pollination and natural enemies for pest control. However, to our knowledge, a complete appraisal of the pros and cons of flower strips, from a farmer's point of view, does not yet exist. It is proposed that better and more complete information could increase the adoption and implementation of such agri-environmental schemes.

Objectives. This study aims 1) to assess the pros and cons of flower strips, from a farmer's point of view, and 2) to highlight the knowledge gaps that exist in the scientific literature, for the different types of pros and cons.

Method. We listed the different components of the appraisal of pros and cons and conducted a systematic screening of the scientific literature on flower strips and these components.

Results. The largest part of the 31 selected studies was concerning agronomical and ecological processes, such as pollination and animal pest control. Most of them indicated positive effects of flower strips. For many components of the appraisal, mostly economic and social ones, few or no studies were found.

Conclusions. While a positive balance of pros and cons, from a farmer's point of view, came from our literature screening, large research gaps still remain and more research is required, especially in the economic and social components of the evaluation.

Keywords. Agroecosystems, ecosystem services, sustainable agriculture, agricultural practices, intensive farming, crop yield, compensation, farm income, attitudes, biological control.

\section{Avantages et inconvénients des bandes fleuries pour les agriculteurs (synthèse bibliographique)}

Description du sujet. Afin de limiter les effets néfastes de l'intensification agricole sur l'environnement, les agriculteurs européens ont la possibilité d'adopter un certain nombre de mesures agri-environnementales. Parmi celles-ci, l'aménagement de bandes fleuries en bordures de parcelles peut soutenir le maintien d'une diversité d'organismes dans le milieu agricole, dont certains peuvent jouer un rôle positif pour l'agriculture, comme la pollinisation ou le contrôle des ravageurs. Néanmoins, une analyse des avantages et inconvénients des mesures agri-environnementales est nécessaire pour favoriser leur adoption par les agriculteurs. En ce qui concerne les bandes fleuries, une telle analyse n'est actuellement pas disponible.

Objectifs. Cette étude a pour objectif 1) d'évaluer le rapport entre les avantages et les inconvénients des bandes fleuries pour l'agriculteur et 2) de mettre en évidence les manques de connaissances à propos de ceux-ci au sein de la littérature scientifique. Méthode. Après avoir listé différentes composantes du rapport entre les avantages et les inconvénients des bandes fleuries, une revue systématique de la littérature scientifique a été réalisée.

Résultats. La majorité des 31 articles sélectionnés traitaient de processus agronomiques et écologiques tels la pollinisation et le contrôle biologique. La plupart montraient un intérêt des bandes fleuries. Néanmoins, peu d'études traitaient les autres aspects considérés par la présente analyse, notamment les aspects socio-économiques. 
Conclusions. En pesant le pour et le contre, il ressort de cette étude que les bandes fleuries sont plutôt favorables pour l'agriculteur. Néanmoins, un manque de connaissance scientifique a été mis en évidence, notamment concernant les aspects économiques et sociaux liés à ce type de mesures.

Mots-clés. Agroécosystème, services écosystémiques, agriculture durable, pratique agricole, agriculture intensive, rendement des cultures, indemnisation, revenu de l'exploitation, attitude, lutte biologique.

\section{INTRODUCTION}

Agricultural intensification during the last few decades has led to large biodiversity losses, due to habitat destruction and fragmentation, increased field size, simplified crop rotations and intensification of crop management (Kruess et al., 1994; Stoate et al., 2001; Tscharntke et al., 2005). Simultaneously, the concept of Ecosystem Services (ES) arose, defined as the benefits that people obtain from ecosystems (Millenium Ecosystem Assessment, 2005). In the field of agriculture, ES are, among others, biomass production, pollination, pest control, soil conservation and fertility (Zhang et al., 2007). As biodiversity is known to play a key role in ES, biodiversity losses can cause disruption of ES delivered by the agricultural landscape (Tscharntke et al., 2005; Zhang et al., 2007). Increasing and restoring biodiversity in the agricultural landscape can, thus, be a strategy to support these ES. Therefore, European farmers are encouraged through European subsidies of the Common Agricultural Policy to implement agri-environmental schemes, such as planting hedgerows, grass buffer strips or flower strips (European Commission, 2005; Haaland et al., 2011). A flower strip is a part of a field that is preserved for herbaceous vegetation. The strip can be created by sowing a mixture of forb species, with or without grass species. The strip can also be created by spontaneous vegetation. Both annual and perennial strips exist. The type of strips, management and subsidies vary considerably between countries, depending on their policy (Haaland et al., 2011). The main goal of flower strips is to enhance farmland biodiversity by providing food and shelter for insects and other animals, and an area for wild plants to grow and reproduce (Haaland et al., 2011). Additionally, their focus is to attract and support functional arthropods like pollinators (Nicholls et al., 2012) and natural enemies (Landis et al., 2000). These functional arthropods can be beneficial to the crop by delivering pollination and pest control services and can reduce inputs like pesticide use or renting bee hives (Haaland et al., 2011), making flower strips a valuable measure to play a role in ecological intensification (Bommarco et al., 2013). Apart from supporting and attracting functional arthropods, habitat enhancement, like the implementation of flower strips, can also provide other advantages, such as reduction of soil erosion or improvement of the landscape's aesthetic value (Fiedler et al., 2008; Wratten et al., 2012).
While some of these advantages have already been shown, agri-environmental schemes have been discussed over the years, as they are not always effective (Batáry et al., 2015). Reviews exist on sown flower strips (Haaland et al., 2011) or field margins (Marshall et al., 2002), but they are restricted to the effect of sown flower strips on insect conservation (Haaland et al., 2011) and interactions of field margins with agriculture (Marshall et al., 2002) and do not provide a complete appraisal of the advantages and disadvantages of flower strips. Some attempts have been made to evaluate the pros and cons of habitat enhancement, such as in Fiedler et al.(2008) and Wratten et al. (2012), but not yet for flower strips specifically. Bommarco et al. (2013) argue that existing knowledge gaps on several services and processes, as well as on their synergies and trade-offs, have implications for decision making in ecological intensification measures. Moreover, many studies about the farmers' attitude towards the adoption of agri-environmental schemes demonstrate the importance of providing information on the diverse aspects of their implementation (Vanslembrouck et al., 2002; Mathijs, 2003; Mante et al., 2007; Sattler et al., 2010; Burton et al., 2011). Apart from environmental concern, compensation rates and the effect on agronomic production, the farmers' acceptance of agri-environmental schemes is also driven by implementation time and effort, effectiveness, associated risks, additional transaction costs, their ease in communication and their relations with the subsidizing institution and its contact person (Falconer, 2000; Mathijs, 2003; Mante et al., 2007; Sattler et al., 2010). It was shown that farmers who are more informed and more convinced about the usefulness of agri-environmental schemes, are more likely to implement them in their farms (Vanslembrouck et al., 2002). Moreover, Burton et al. (2011) argue that this information would increase the adoption of environmental practices in their farming culture and conventional "good farming" practice. Therefore, it could be useful to gain comprehensive insight into the advantages and disadvantages of the implementation of flower strips for farmers (Fiedler et al., 2008; Wratten et al., 2012). In this context, we conducted a systematic literature screening aiming at:

- assessing the pros and cons from a farmer's point of view,

- highlighting the knowledge gaps in the literature for the different types of pros and cons. 


\section{LITERATURE SCREENING}

To make an appraisal of the pros and cons of flower strips, a list was made of the possible different components of this appraisal, that is, aspects of the farming system that may be influenced by a flower strip. This list of components was iteratively composed and completed by a panel of experts. This panel was comprised of the authors of this manuscript, being researchers and professors with a MSc or $\mathrm{PhD}$ degree and having expertise in crop science, ecology, weed science, ecosystem service valuation, agroecology, food science, pollination and biological control. The components can be found in table $\mathbf{1}$. They were divided into four categories:

- agronomical and ecological processes: the effect on the crop of ecosystem processes in the flower strip;

- economic balance (costs): the different economic inputs that can be influenced by flower strips;

- economic balance (income): the different economic outputs that can be influenced by flower strips;

- social recognition: the different ways that a farmer's relationship with other stakeholders can be influenced by flower strips, and the farmer's perception of flower strips.

For each component, a search query was done in Scopus (Elsevier B.V., 2014) scientific literature database on 31 October 2014. For this, keywords were chosen to find literature addressing flower strips and the respective component. The query syntax required the papers to have title, abstract or keywords containing at least one of the search terms about flower strips and at least one of the search terms about the respective component. The search terms about flower strips were "flower strip(s)", "wildflower strip(s)", "flowering border(s)", "flower margin(s)", "margin strip(s)", "sown strip(s)", "sown margin(s)", "sown margin strip(s)", "weed strip(s)", "sown weed strip(s)", "herb strip(s)", "sown herb strip(s)", "field margin(s) AND sowing", "field boundary/boundaries AND sowing" and "field border(s) AND sowing". The search terms for the components are listed in table 1. Search terms were chosen to find as many papers as possible that were clearly about flower strips and the respective component. For this, the list of search terms was again subject to validation by the panel of experts.

To retain only the papers that met the objectives of this review, the references obtained from the Scopus search query were listed, per component, and divided between the authors to select the references of interest based on a set of criteria (see below). If an abstract was not available, the reference was not considered. Review papers were not considered, as these are based on other studies. Double records, or studies published more than once, were only considered once.
To be selected, a paper had to meet four criteria. Firstly, the study had to be about flower strips, a part of a field that contained one or more forb (herbaceous flowering) species. This part could be at the margin or inside the field, the vegetation could be spontaneous or sown, the plant species could be native or not, and annual or perennial. Excluded were pure grass strips, hedgerows (strips of ligneous plants), crop associations and companion plants. Included were strips where a crop and annual forbs were mixed. The decision for this criterion was made based on the abstract, but if the detailed characteristics of the flower strip could not be derived from the abstract, they were verified in the body of the article. Secondly, the study had to be conducted in an agricultural context. This means that the part of the field, that is not flower strip, had to be cropland, pasture or orchard. It also means the study had to be conducted in the field, not in controlled conditions (lab, greenhouse, growth chamber, etc.). The decision was taken based on the abstract, but if the agricultural context was not clear from the abstract, it was verified in the body of the article. Thirdly, the study had to be about the respective component of the appraisal. For this, a clear question was formulated for each component to evaluate the abstracts. The questions are listed in table 1. This criterion had to be clear from the abstract. As the presence of a healthy pollinator community and a healthy natural enemy community are considered to be beneficial for crop pollination and crop pest control, respectively (e.g. Tscharntke et al., 2007; Hoehn et al., 2008; Albrecht et al., 2012; Tschumi et al., 2015; Winfree et al., 2015; but see Chaplin-Kramer et al., 2011), they were also used in the third criterion for the components "pollination" and "animal pests". For this third criterion, the selection procedure was cross-checked by providing the set of references, meeting each criterion, to another author to evaluate them again, with the third criterion. Fourthly, the study had to be conducted in the North Temperate Zone (between the Arctic Circle and the Tropic of Cancer). If this was not clear from the abstract, it could be verified in the body of the article.

Based on the number of selected papers per component, the knowledge gaps and research needs were highlighted. The selected papers were then screened for the type of effect they showed. We considered as an effect a relationship, found in a study, showing an influence of flower strips on the considered component: a "positive effect" if the study showed that flower strips had a significant influence on the component that was beneficial for the farmer; a "negative effect" if the study showed that flower strips had a significant influence on the component that was disadvantageous for the farmer; and a "neutral effect" if the study contained a relationship for which no significant influence on the component could be 


:

훈

:

退

تृ

范

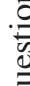

党:

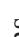

幽

䨔

幽

.

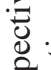

온

홀

ㄴ.

莪

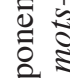

赔

里

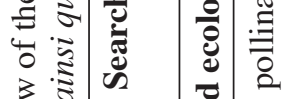

.

o.

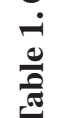

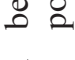

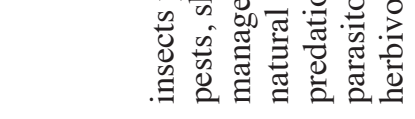

융퓨 힐

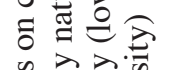

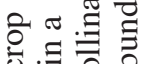

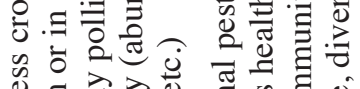

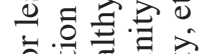

可的司

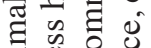

寻光它苞

: $\Xi$ ฮे

$\gtrsim$

。ี

范甼夏

월

夏苍离

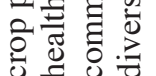

언 Ð

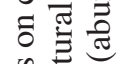

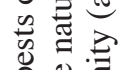

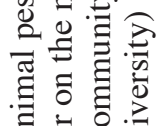

ठ্

0 o

范

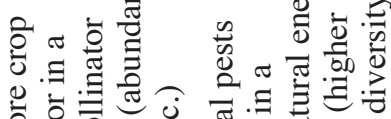

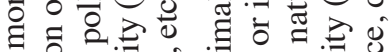

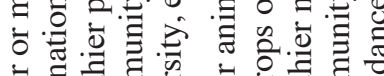

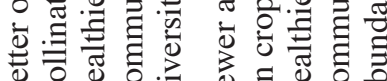

สี

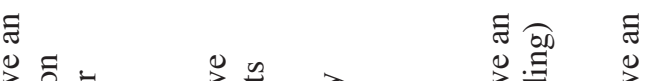

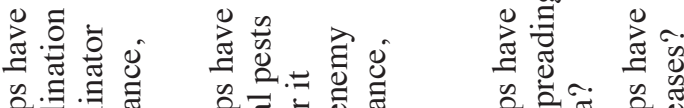

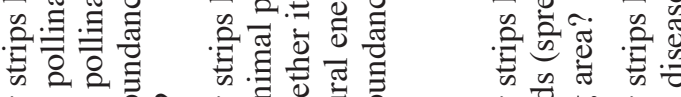

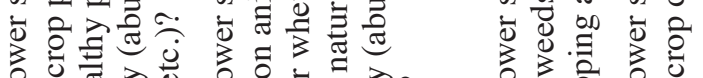

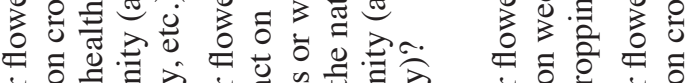

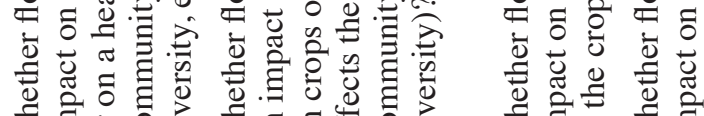

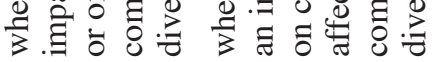

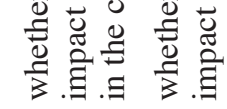

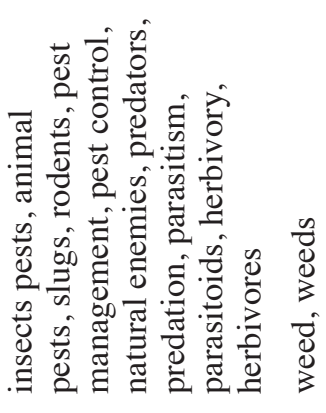

范

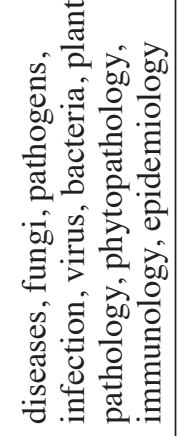

0
0
0
0
0
0

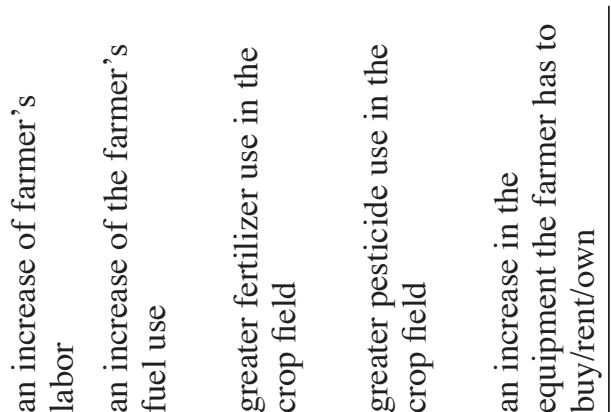

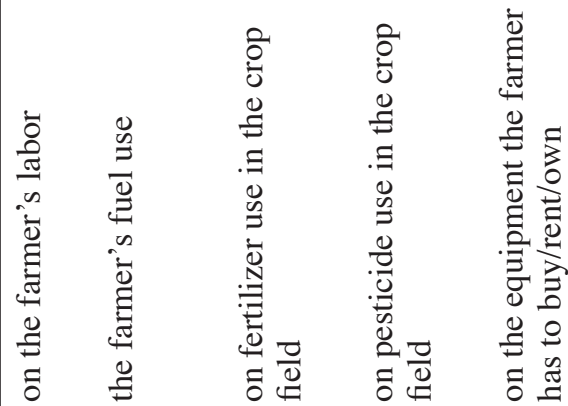

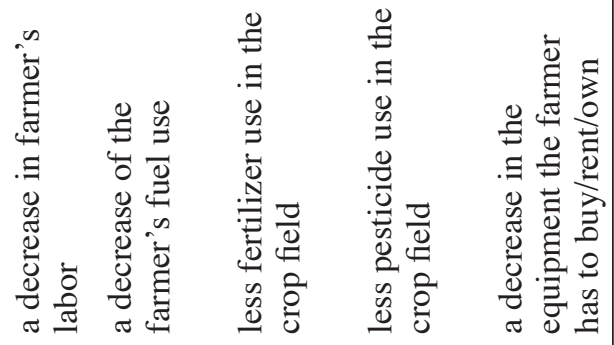

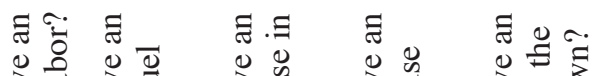

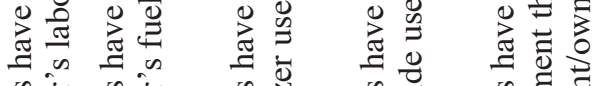

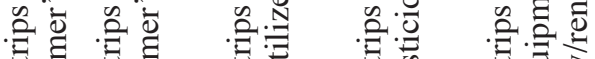

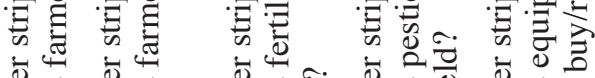

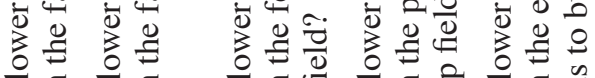

б

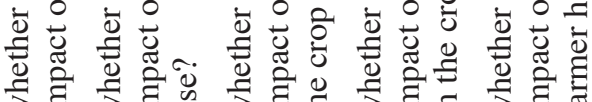

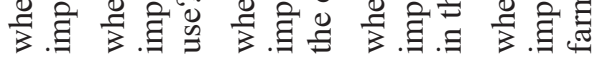
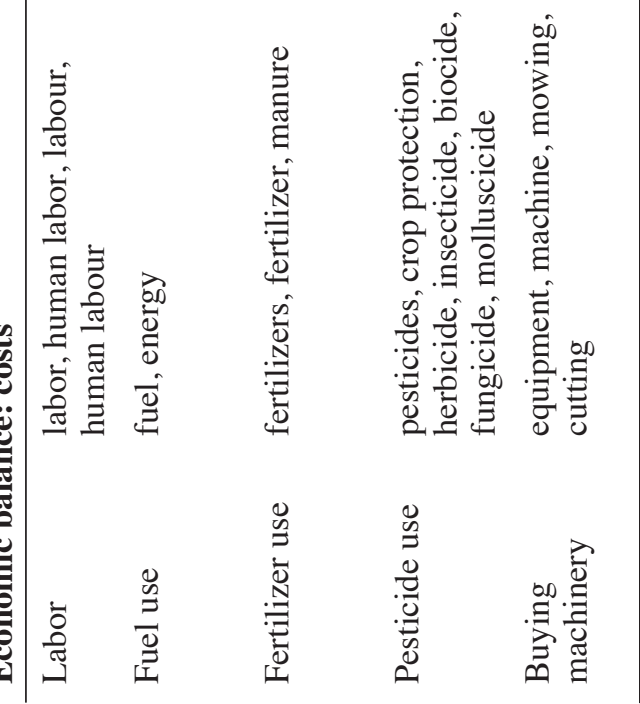


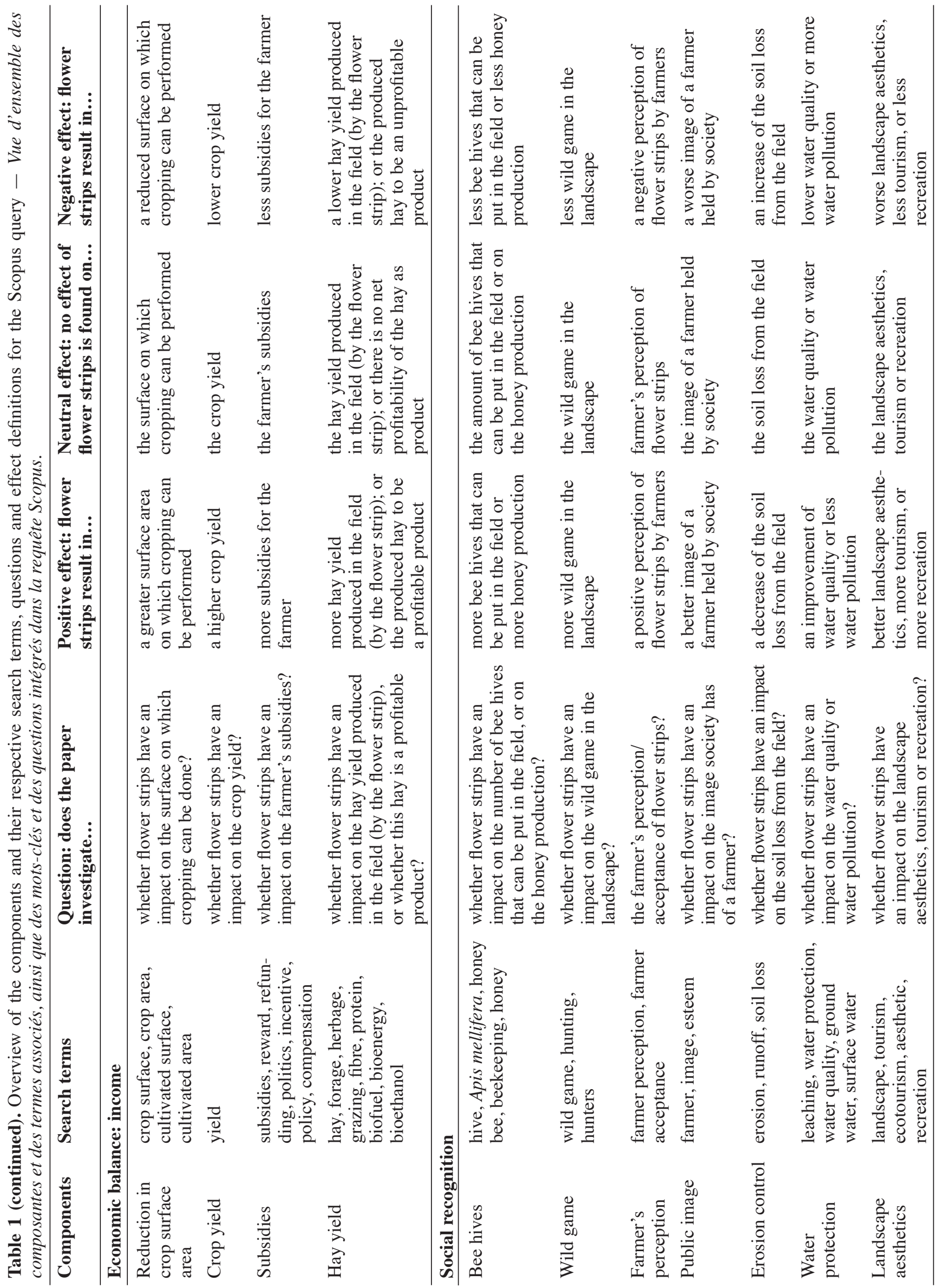


shown (see table 1 for a clear definition of the effects per component). A single paper could show positive, neutral, as well as negative effects, which, in that case, were all considered. If a paper showed an effect for which no statistical test was needed, it was also taken into consideration. The information on the effects was based on the abstract, but if the information could not be derived from the abstract, it was verified in the body of the article. The effects were summed, per component, to identify the predominant effect.

\section{FLOWER STRIPS' PROS AND CONS FOR FARMERS: A POSITIVE BALANCE SO FAR}

The Scopus search retrieved 245 unique records, among which some appeared for several components, resulting in a total of 593 records. Only 34 records met the criteria for selection, of which 30 were unique papers. The selected papers addressed 6 of the 20 components (see table 2): pollination, animal pests, weeds, subsidies, hay yield and wild game. Most selected papers addressed the animal pests component (18), followed by pollination (7) and weeds (6). Figure 1 shows a radar plot of the log-transformed (log $[n+1])$ number of selected papers, for each component. Most selected papers (31 out of 34) appeared in the "agronomical and ecological processes" category, while the components of the other categories had only one selected paper, or none at all.

Figure 2 shows the percentage of positive, negative and neutral effects (from a farmer's point of view) of the selected papers, for each component. In total, $80 \%$ of the papers reported positive effects, $24 \%$ reported negative effects and $29 \%$ reported neutral effects. This resulted in 27 positive effects reported, 10 negative effects and 8 neutral effects. As explained before, a single paper could contain a positive, a negative, as well as a neutral effect. There was not a single case among the components where the negative effects outweighed the positive effects. While this already suggests a positive balance of pros and cons, the lack of research for most of components makes it too early to draw any general conclusions.

For the pollination component, all seven selected papers showed a positive effect, being an increase in either abundance or diversity of pollinators, or both. Marshall et al. (2002) and Haaland et al. (2011) already mentioned some work suggesting the beneficial effect of flower strips for pollinators in their reviews. Five out of these papers considered bumblebees as the taxonomic group to study pollination. No paper was found investigating the effect on crop pollination explicitly.

For the animal pests component, 13 papers showed a positive effect, 5 papers showed a negative effect, and 8 papers contained a neutral effect. Effects concerned either an increase or decrease in abundance or diversity of pests, either an increase or decrease in abundance or diversity of natural enemies, or both. The positive effects, consisting in the reduction of pests or the increase of natural enemies, have also been mentioned in the review of Marshall et al. (2002) while the reviewed papers in Haaland et al. (2011) also showed mixed effects (reviewed papers partly overlapping with the papers in the present review). While abundance was the most frequently used metric, four papers also studied diversity, or species richness, of pests or natural enemies. Some of the papers indicated that effects can be species dependent (Roy et al., 2008; Pfiffner et al., 2009). Also for this component, papers tended to report an effect on the abundance or the diversity of pest and natural enemy species, and not on crop damage, per se.

While increased abundance or diversity of pollinators and natural enemies have already been shown to increase crop pollination and decrease crop damage, respectively (Tscharntke et al., 2007; Hoehn

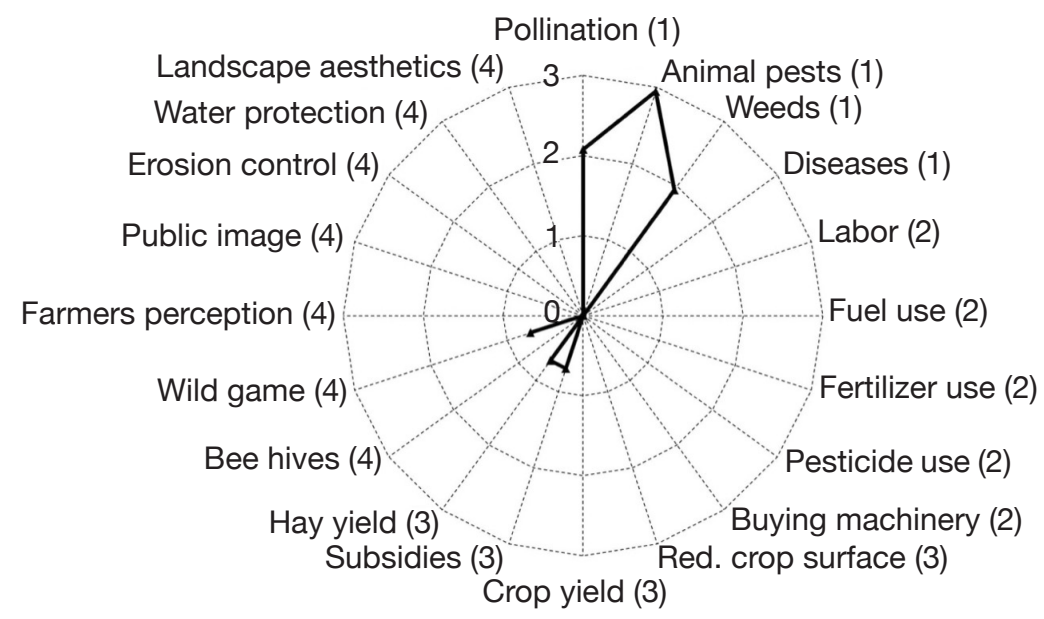

Figure 1. Radar plot of the log-transformed $(\log [n+1])$ number of papers selected for each component - Graphique radar du nombre d'articles sélectionnés pour chacune des composantes (après transformation logarithmique $(\log [n+1])$.

Numbers between brackets indicate the category to which the component belongs, with (1) being "Agronomical and ecological processes", (2) "Economic balance: costs", (3) "Economic balance: income" and (4) "Social recognition" - les nombres entre parenthèses indiquent la catégorie à laquelle chacune des composantes correspond avec (1) "Processus agronomiques et écologiques », (2)

«Équilibre économique : couts», (3) «Équilibre économique : revenu » et (4)

«Reconnaissance par la société ». 
Table 2. Results of the Scopus query, with for each component the number of papers in the query output, the number of papers that met the criteria for selection and the references of these papers - Résultats des requêtes Scopus, avec pour chacune des composantes le nombre d'articles obtenus par la requête, le nombre d'articles correspondant à la sélection et leurs références.

\begin{tabular}{|c|c|c|c|}
\hline Components & $\begin{array}{l}\text { Number of } \\
\text { papers output }\end{array}$ & $\begin{array}{l}\text { Number of } \\
\text { selected papers }\end{array}$ & References of selected papers \\
\hline Pollination & 23 & 7 & 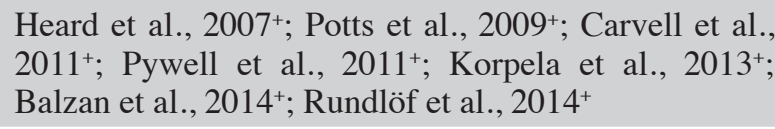 \\
\hline Animal pests & 95 & 18 & 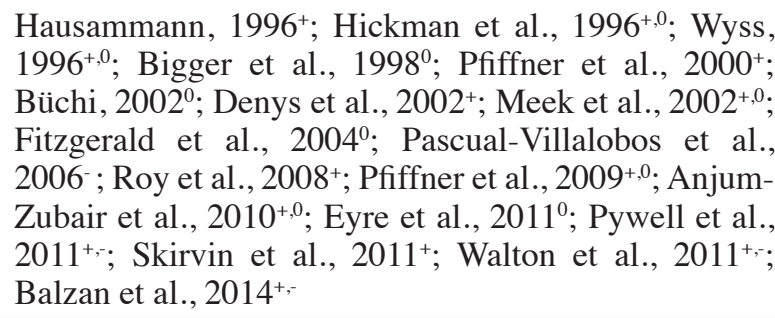 \\
\hline Weeds & 71 & 6 & 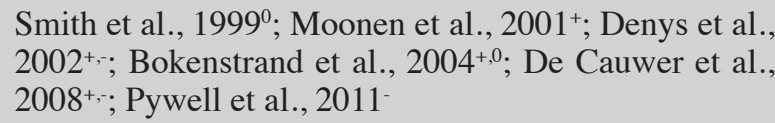 \\
\hline Diseases & 15 & 0 & \\
\hline Labor & 0 & 0 & \\
\hline Fuel use & 7 & 0 & \\
\hline Fertilizer use & 30 & 0 & \\
\hline Pesticide use & 73 & 0 & \\
\hline Buying machinery & 46 & 0 & \\
\hline Reduction crop surface area & 41 & 0 & \\
\hline Crop yield & 35 & 0 & \\
\hline Subsidies & 58 & 1 & Mante et al., $2007^{+}$ \\
\hline Hay yield & 38 & 1 & De Cauwer et al., 2006 ${ }^{+}$ \\
\hline Bee hives & 8 & 0 & \\
\hline Wild game & 13 & 1 & Casas et al., $2010^{+}$ \\
\hline Farmers perception & 0 & 0 & \\
\hline Public image & 24 & 0 & \\
\hline Erosion control & 8 & 0 & \\
\hline Water protection & 5 & 0 & \\
\hline Landscape aesthetics & 3 & 0 & \\
\hline
\end{tabular}

${ }^{+}:$the paper shows a positive effect - l'article montre un effet positif, $:$: the paper shows a negative effect - l'article montre un effet négatif; '0': the paper shows a neutral effect - l'article montre un effet neutre.

et al., 2008; Albrecht et al., 2012; Tschumi et al., 2015; Winfree et al., 2015), this relationship is not found in all studies (Chaplin-Kramer et al., 2011). This suggests that more research is required to explore under what conditions this relationship is valid or not, and that studies on flower strips should focus on the direct effects on crop pollination and crop damage.

For the weeds component, three papers showed a negative effect, four papers showed a positive effect, and two papers contained a neutral effect. There was a clear link to the type of flower strip vegetation: negative effects were reported for flower strips with spontaneous vegetation, in which noxious weeds could easily settle within the vegetation, while positive and neutral effects were reported for sown flower strips, in which the competitive sown species were able to suppress harmful weed species from settling in the strip. Marshall et al. (2002) also mention research pointing out that sowing grass, or grass and flower mixes, reduces the risk of weed spreading. 


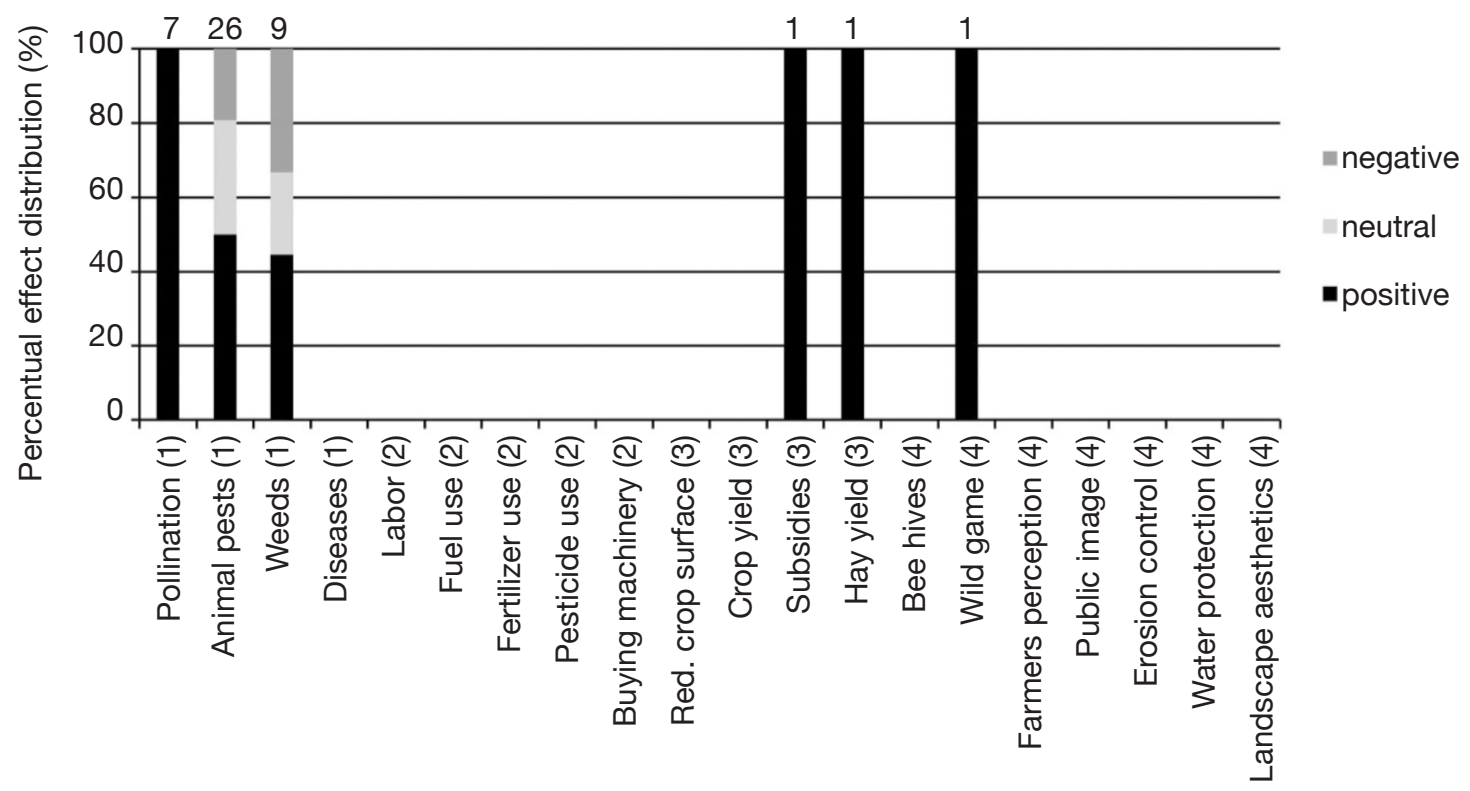

Figure 2. Bar chart with the percentage distribution of positive, negative and zero effects for each component (see table 2) - Histogramme de la proportion d'articles (en \%) présentant un effet positif, négatif ou neutre, par composante traitée (voir le tableau 2 ).

Numbers above the bars indicate the number of effects identified in the selected papers, for that component - les nombres au-dessus des barres indiquent le nombre d'effets identifiés au sein des articles sélectionnés pour chacune des composantes; components without a bar had no selected papers - lorsqu'aucun article n'a été sélectionné, aucune barre n'est indiquée; numbers between brackets indicate the category to which the component belongs, with (1) being "Agronomical and ecological processes", (2) "Economic balance: costs", (3) "Economic balance: income" and (4) "Social recognition" - les nombres entre parenthèses indiquent la catégorie à laquelle chacune des composantes correspond avec (1) «Processus agronomiques et écologiques », (2) «Équilibre économique : couts», (3) « Équilibre économique : revenu » et (4) «Reconnaissance par la société ».

For the subsidies, the hay yield as well as the wild game component, only one paper was selected, each one showing a positive effect of flower strips. For the other components, either no papers were found or the papers did not meet the criteria. The small number of selected papers, therefore, makes it impossible to draw general conclusions. However, for certain components, the effects of flower strips might be obvious. For example, flower strips can produce hay, while crops mostly do not. Hay yield is, thus, expected not to be negatively affected by implementing flower strips instead of crops.

\section{RESEARCH GAPS AND NEED FOR FURTHER RESEARCH}

While a total of 593 records came out of the database query, only 34 met the criteria for inclusion. This shows that, from the considerable amount of research on flower strips, only a few studies explicitly considered the influence of flower strips in terms of the advantages or disadvantages for the farmer. For pollination, animal pests, and weeds, many papers had to be excluded as they reported on insects or weeds in the crop or flower strip, without a proper comparison to a no-strip control. This partly explains the low number of selected papers for these components, and suggests the need for well-designed field studies to demonstrate the effects of flower strips. Moreover, only one study was carried out over 10 years, while the other studies lasted only for four years or less. More long-term research could, therefore, produce interesting results, even if agri-environmental schemes like flower strips are often based on a short-term agreement (Service public de Wallonie, 2012) and their advantages for farmers should be present already in the short term. The selected papers on the pollination component were all more recent, with all selected papers published after 2006. For the other components, selected papers were equally spread over time starting from 1996.

Thirty-one papers reported on research conducted in Europe, while only three were conducted in the USA. This suggests that more research is done on flower strips in Europe, possibly as a result of the variable subsidizing policy in the EU and the USA for creating flower strips (Haaland et al., 2011; USDA, 2015). The majority of the selected studies (30) were conducted 
on flower strips adjacent to arable crops. Only three studies looked at flower strips in orchards, and only one examined flower strips in pastureland.

Marshall et al. (2002) and Haaland et al. (2010) mentioned some other practical advantages of flower strips for farmers that we did not consider. Flower strips can be used for turning tractors or other agronomic vehicles, for visual inspection for pests and weeds, for hedge or other boundary management without disturbing or damaging the crop, or for recreational pathways (Marshall et al., 2002; Haaland et al., 2010). However, depending on the country, agrienvironmental scheme regulations may prohibit one or more of these uses, e.g. tractor turning may cause disturbance of the vegetation and fauna in the strip (Service public de Wallonie, 2012).

The evaluation of pros and cons could also depend on the type of flower strip. A perennial strip with successively flowering plant species, providing continuous pollen and nectar resources, would be the preferred option to support pollinators (Wratten et al., 2012). For biological pest control, however, targeted annual strips with flower species adapted to the crop rotation, would be preferred (e.g. Tschumi et al., 2015), while for erosion control and water protection, simple grass strips would be sufficient. This suggests the need to analyze the trade-offs between the different pros and cons in the context of the particular farm.

Furthermore, the choice of seed mixture, and the management of flower strips, will determine the vegetation development during the years following establishment (De Cauwer et al., 2005; Uyttenbroeck et al., 2015). This can consequently influence the evaluation of pros and cons. Seed mixture and management differ between countries and geographical regions. Management can include one or more cutting a year, with or without hay removal, or no cutting at all (Haaland et al., 2011). De Cauwer et al. (2006) already showed a difference in hay yield and herbage quality between sown and unsown flower strips, but more research on this and other components is needed.

The majority of the selected papers belonged to the category of "agronomical and ecological processes", while there is a paucity of research in the "economic balance: costs", the "economic balance: income" and the "social recognition" categories. This indicates that, along with more research in the agronomical and ecological processes, interactions with researchers from Economics and Social Sciences could be useful to provide a more complete evaluation of pros and cons, which is necessary for effective ecological intensification (Bommarco et al., 2013). This research can be compared with the findings about factors determining farmers' acceptance of agri-environmental schemes (Vanslembrouck et al., 2002; Mathijs, 2003; Mante et al., 2007; Sattler et al., 2010; Burton et al.,
2011) to identify the aspects on which farmers need more information. A better and more informed farmer is more likely to implement agri-environmental measures (Vanslembrouck et al., 2002; Fiedler et al., 2008; Wratten et al.,2012) and could adopt this practice in his farming culture (Burton et al., 2011). However, studies on farmers' trajectories from intensive agriculture to more sustainable agricultural systems demonstrate that information is only one of the factors determining if, how and how fast a farmer will make a transition to a more sustainable farming system (Lamine, 2011; Chantre et al., 2014). The so-called "lock-in" effect can even force farmers to keep their conventional agricultural practices, and should be taken into account when promoting measures like flower strips (Cowan et al., 1996; Wilson et al., 2001).

\section{CONCLUSIONS}

We can conclude that so far, the balance of pros and cons of flower strips, from a farmers' point of view, tends to be positive. This was, however, mostly the case for agronomical and ecological processes, like pollination and animal pest control. Weed infestation was only less problematic for sown flower strips, while spontaneous ones tended to increase weed problems. For the other components of the appraisal, large research gaps are still present, especially in terms of the influence of flower strips on the farmer's economical balance and social recognition. We expect that more research on the different components of the appraisal of pros and cons, combined with better information for farmers, can lead to a higher uptake of flower strips in farming.

\section{Acknowledgements}

This research was funded by the CARE AgricultureIsLife, University of Liège - Gembloux Agro-Bio Tech, Belgium.

\section{Bibliography}

Albrecht M. et al., 2012. Diverse pollinator communities enhance plant reproductive success. Proc. R. Soc. London Ser. B, 279(1748), 4845-4852.

Anjum-Zubair M. et al., 2010. Influence of within-field position and adjoining habitat on carabid beetle assemblages in winter wheat. Agric. For. Entomol., 12(3), 301-306.

Balzan M.V., Bocci G. \& Moonen A.-C., 2014. Augmenting flower trait diversity in wildflower strips to optimise the conservation of arthropod functional groups for multiple agroecosystem services. J. Insect Conserv., 18(4), 713728. 
Batáry P. et al., 2015. The role of agri-environment schemes in conservation and environmental management. Conserv. Biol., 29(4), 1006-1016.

Bigger D.S. \& Chaney W.E., 1998. Effects of Iberis umbellata (Brassicaceae) on insect pests of cabbage and on potential biological control agents. Environ. Entomol., 27(1), 161-167.

Bokenstrand A., Lagerlöf J. \& Torstensson P.R., 2004. Establishment of vegetation in broadened field boundaries in agricultural landscapes. Agric. Ecosyst. Environ., 101(1), 21-29.

Bommarco R., Kleijn D. \& Potts S.G., 2013. Ecological intensification: harnessing ecosystem services for food security. Trends Ecol. Evol., 28(4), 230-238.

Büchi R., 2002. Mortality of pollen beetle (Meligethes spp.) larvae due to predators and parasitoids in rape fields and the effect of conservation strips. Agric. Ecosyst. Environ., 90(3), 255-263.

Burton R.J.F. \& Paragahawewa U.H., 2011. Creating culturally sustainable agri-environmental schemes. J. Rural Stud., 27(1), 95-104.

Carvell C. et al., 2011. Bumble bee species' responses to a targeted conservation measure depend on landscape context and habitat quality. Ecol.Appl., 21(5), 1760-1771.

Casas F. \& Viñuela J., 2010. Agricultural practices or game management: which is the key to improve red-legged partridge nesting success in agricultural landscapes? Environ. Conserv., 37(02), 177-186.

Chantre E. \& Cardona A., 2014. Trajectories of French field crop farmers moving toward sustainable farming practices: change, learning, and links with the advisory services. Agroecol. Sustainable Food Syst., 38(1-5), 573 602.

Chaplin-Kramer R. et al., 2011. A meta-analysis of crop pest and natural enemy response to landscape complexity. Ecol. Lett., 14(9), 922-932.

Cowan R. \& Gunby P., 1996. Sprayed to death: path dependence, lock-in and pest control strategies. Econ.J., 106(436), 521-542.

De Cauwer B. et al., 2005. Evolution of the vegetation of mown field margins over their first 3 years. Agric. Ecosyst. Environ., 109(1), 87-96.

De Cauwer B. et al., 2006. Dry matter yield and herbage quality of field margin vegetation as a function of vegetation development and management regime. NJASWageningen J. Life Sci., 54(1), 37-60.

De Cauwer B. et al., 2008. Management of newly established field margins on nutrient-rich soil to reduce weed spread and seed rain into adjacent crops. Weed Res., 48(2), 102112.

Denys C. \& Tscharntke T., 2002. Plant-insect communities and predator-prey ratios in field margin strips, adjacent crop fields, and fallows. Oecologia, 130(2), 315-324.

Elsevier B.V., 2014. Scopus, http://www.scopus.com

European Commission, 2005. Agri-environment measures: overview on general principles, types of measures and application. European Commission, Directorate General for Agriculture and Rural Development.

Eyre M.D. et al., 2011. Relationships between beneficial invertebrates, field margin vegetation, and thrip damage in organic leek fields in eastern England. Org. Agric., 1(1), 45-54.

Falconer K., 2000. Farm-level constraints on agrienvironmental scheme participation: a transactional perspective. J. Rural Stud., 16(3), 379-394.

Fiedler A.K., Landis D.A. \& Wratten S.D., 2008. Maximizing ecosystem services from conservation biological control: the role of habitat management. Biol. Control, 45(2), 254-271.

Fitzgerald J.D. \& Solomon M.G., 2004. Can flowering plants enhance numbers of beneficial arthropods in UK apple and pear orchards? Biocontrol Sci. Technol., 14(3), 291-300.

Haaland C. \& Gyllin M., 2010. Butterflies and bumblebees in greenways and sown wildflower strips in southern Sweden. J. Insect Conserv., 14(2), 125-132.

Haaland C., Naisbit R.E. \& Bersier L.-F., 2011. Sown wildflower strips for insect conservation: a review. Insect Conserv. Divers., 4(1), 60-80.

Hausammann A., 1996. The effects of weed stripmanagement on pests and beneficial arthropods in winter wheat fields. Z. Pflanzenkrankh. Pflanzenschutz, 103(1), 70-81.

Heard M.S. et al., 2007. Landscape context not patch size determines bumble-bee density on flower mixtures sown for agri-environment schemes. Biol. Lett., 3(6), 638-641.

Hickman J.M. \& Wratten S.D., 1996. Use of Phacelia tanacetifolia strips to enhance biological control of aphids by overfly larvae in cereal fields. J. Econ. Entomol., 89(4), 832-840.

Hoehn P. et al., 2008. Functional group diversity of bee pollinators increases crop yield. Proc. R. Soc. Lond. Ser. $B, 275$ (1648), 2283-2291.

Korpela E.-L. et al., 2013. Can pollination services, species diversity and conservation be simultaneously promoted by sown wildflower strips on farmland? Agric. Ecosyst. Environ., 179, 18-24.

Kruess A. \& Tscharntke T., 1994. Habitat fragmentation, species loss, and biological control. Science, 264(5165), 1581-1584.

Lamine C., 2011. Transition pathways towards a robust ecologization of agriculture and the need for system redesign. Cases from organic farming and IPM. J. Rural Stud., 27(2), 209-219.

Landis D.A., Wratten S.D. \& Gurr G.M., 2000. Habitat management to conserve natural enemies of arthropod pests in agriculture. Annu. Rev. Entomol., 45(1), 175201.

Mante J. \& Gerowitt B., 2007. A survey of on-farm acceptance of low-input measures in intensive agriculture. Agron. Sustainable Dev., 27(4), 399406. 
Marshall E.J.P. \& Moonen A.C., 2002. The ecology of field margins in European farming systems: their functions and interactions with agriculture. Agric. Ecosyst. Environ., 89(1-2), 5-21.

Mathijs E., 2003. Social capital and farmers' willingness to adopt countryside stewardship schemes. Outlook Agric., 32(1), 13-16.

Meek B. et al., 2002. The effect of arable field margin composition on invertebrate biodiversity. Biol. Conserv., 106(2), 259-271.

Millenium Ecosystem Assessment, 2005. Ecosystems and human well-being: synthesis. Washington: Island Press.

Moonen A.C. \& Marshall E.J.P., 2001. The influence of sown margin strips, management and boundary structure on herbaceous field margin vegetation in two neighbouring farms in southern England. Agric. Ecosyst. Environ., 86(2), 187-202.

Nicholls C.I. \& Altieri M.A., 2012. Plant biodiversity enhances bees and other insect pollinators in agroecosystems. A review. Agron. Sustainable Dev., 33(2), 257-274.

Pascual-Villalobos M.J. et al., 2006. Effect of flowering plant strips on aphid and syrphid populations in lettuce. Eur. J. Agron., 24(2), 182-185.

Pfiffner L. et al., 2009. Impact of wildflower strips on biological control of cabbage lepidopterans. Agric. Ecosyst. Environ., 129(1-3), 310-314.

Pfiffner L. \& Luka H., 2000. Overwintering of arthropods in soils of arable fields and adjacent semi-natural habitats. Agric. Ecosyst. Environ., 78(3), 215-222.

Potts S.G. et al., 2009. Enhancing pollinator biodiversity in intensive grasslands. J. Appl. Ecol., 46(2), 369-379.

Pywell R.F. et al., 2011. Ecological restoration on farmland can drive beneficial functional responses in plant and invertebrate communities. Agric. Ecosyst. Environ., 140(1-2), 62-67.

Roy G. et al., 2008. Refuges, flower strips, biodiversity and agronomic interest. Commun. Agric. Appl. Biol. Sci., 73(3), 351-359.

Rundlöf M. et al., 2014. Late-season mass-flowering red clover increases bumble bee queen and male densities. Biol. Conserv., 172, 138-145.

Sattler C. \& Nagel U.J., 2010. Factors affecting farmers' acceptance of conservation measures - A case study from north-eastern Germany. Land Use Policy, 27(1), 70-77.

Service public de Wallonie, 2012. Les subventions agroenvironnementales: vade-mecum. Namur, Belgique: Service public de Wallonie.
Skirvin D.J. et al., 2011. The effect of within-crop habitat manipulations on the conservation biological control of aphids in field-grown lettuce. Bull. Entomol. Res., 101(06), 623-631.

Smith H., Firbank L.G. \& Macdonald D.W., 1999. Uncropped edges of arable fields managed for biodiversity do not increase weed occurrence in adjacent crops. Biol. Conserv., 89(1), 107-111.

Stoate C. et al., 2001. Ecological impacts of arable intensification in Europe. J. Environ. Manage., 63(4), 337-365.

Tscharntke T. et al., 2005. Landscape perspectives on agricultural intensification and biodiversity - ecosystem service management. Ecol. Lett., 8(8), 857-874.

Tscharntke T. et al., 2007. Conservation biological control and enemy diversity on a landscape scale. Biol. Control, 43(3), 294-309.

Tschumi M. et al., 2015. High effectiveness of tailored flower strips in reducing pests and crop plant damage. Proc. R. Soc. Ser. B, 282(1814), 20151369.

USDA, 2015. Using 2014 farm bill programs for pollinator conservation. Washington: USDA.

Uyttenbroeck R. et al., 2015. Creating perennial flower strips: think functional! Agric. Agric. Sci. Procedia, 6, 95-101.

Vanslembrouck I., Van Huylenbroeck G. \& Verbeke W., 2002. Determinants of the willingness of Belgian farmers to participate in agri-environmental measures. J. Agric. Econ., 53(3), 489-511.

Walton N.J. \& Isaacs R., 2011. Influence of native flowering plant strips on natural enemies and herbivores in adjacent blueberry fields. Environ. Entomol., 40(3), 697-705.

Wilson C. \& Tisdell C., 2001. Why farmers continue to use pesticides despite environmental, health and sustainability costs. Ecol. Econ., 39(3), 449-462.

Winfree R. et al., 2015. Abundance of common species, not species richness, drives delivery of a real-world ecosystem service. Ecol. Lett., 18, 626-635.

Wratten S.D. et al., 2012. Pollinator habitat enhancement: benefits to other ecosystem services. Agric. Ecosyst. Environ., 159, 112-122.

Wyss E., 1996. The effects of artificial weed strips on diversity and abundance of the arthropod fauna in a Swiss experimental apple orchard. Agric. Ecosyst. Environ., 60(1), 47-59.

Zhang W. et al., 2007. Ecosystem services and dis-services to agriculture. Ecol. Econ., 64(2), 253-260.

(65 ref.) 